\title{
Fish assemblages along a morphodynamic continuum on three tropical beaches
}

\author{
Ronnie E. M. C. C. Oliveira and André L. M. Pessanha
}

A comparative study involving three mesotidal beaches from reflective to estuarine states was conducted between October 2010 and September 2011 in the estuary of Mamanguape River, northeastern Brazil. The aim was to test for differences in fish assemblages along a morphodynamic continuum, particularly the effects of wave action. In total, 3,732 fish from 71 species were examined; Rhinosardinia bahiensis and Atherinella brasiliensis dominated the estuarine beach, whereas Trachinotus carolinus dominated the reflective beach. Fish assemblages were structured by spatial differences among the sites, and overall abundance, richness and biomass demonstrated a clear increasing trend from the reflective to the estuarine beaches, indicating a primary influence of wave exposure in the measured parameters. The Mamanguape River estuary plays a crucial ecological role as a nursery for several species that depend on its resources and have adapted to the high variability of its physical and chemical factors and the diversity of its habitats.

Um estudo comparativo envolvendo três praias mesotidais do estado refletivo para o estuarino foi realizado entre outubro de 2010 e setembro de 2011 no estuário do rio Mamanguape, Nordeste do Brasil. O objetivo foi testar as diferenças nas assembleias de peixes ao longo de um continuum morfodinâmico, particularmente os efeitos da ação das ondas. No total, 3.732 peixes de 71 espécies foram examinados; Rhinosardinia bahiensis e Atherinella brasiliensis dominaram a praia estuarina, enquanto Trachinotus carolinus dominou a praia refletiva. As assembleias de peixes foram estruturadas por diferenças espaciais entre locais de amostragem, e a abundância total, riqueza e biomassa demonstraram uma clara tendência crescente da praia refletiva à praia estuarina, indicando uma influência primária de exposição às ondas nos parâmetros medidos. $\mathrm{O}$ estuário do rio Mamanguape desempenha um papel ecológico importante como um berçário para várias espécies que dependem de seus recursos e se adaptaram à alta variabilidade de seus fatores físico-químicos e da diversidade de seus habitats.

Key words: Community descriptors, Juveniles, Nursery, Spatial patterns, Wave action.

\section{Introduction}

The importance of shallow coastal biotopes in the maintenance of fish assemblages has been clearly demonstrated by studies conducted worldwide (Layman, 2000; Ramos et al., 2006; Kruger \& Strydom, 2010; Woodland et al., 2012). These biotopes are often described as nursery habitats or recruitment areas for fish because they provide a great abundance of food resources and protection from predation. They may also act as a temporary habitat during a particular life cycle phase and/or as a permanent habitat for young-of-the-year, thereby ensuring the renewal of fish stock (McLachlan, 1983; Pessanha et al., 2000; Beck et al., 2001; Able, 2005).
Beaches are defined by McLachlan (1983) as a range of environments on a gradient from open sea to protected sands or mudflats in estuaries. The classification of beaches is performed using several models, including those that consider the beach morphodynamics (Wright \& Short, 1984) and the influence of tides (Short, 1982; Masselink, 1993). In the case of reflective beaches, wave action generates physical stress at these sites that affects sedimentary structure and makes food resources available for fish that can adapt to these conditions (Calliari et al., 2003; Vasconcellos et al., 2007; Niang et al., 2010). Moreover, fish in such environments, with physical conditions created by tides and waves, possess adaptations that may be morphological (Palmeira \& Monteiro-Neto,

Universidade Estadual da Paraíba, Programa de Pós-Graduação em Ecologia e Conservação, Câmpus I, Avenida das Baraúnas, 351, Bairro Universitário, 58429-500, Campina Grande, PB, Brazil. ronnie.enderson@gmail.com (REMCCO); andrepessanhauepb@gmail.com (ALMP) 
2010), or even behavioural adaptations, such as migration to the intertidal zones or other habitats (Harvey, 1998).

In contrast, estuarine beaches are characterized as calmer environments that result from a reduced influence of wave energy (Bernabeu et al., 2012). Several fish species utilize these environments at some stage of their life cycle because of factors such as availability of food from high primary production; availability of refuge provided by structural complexity, especially for juveniles; high water turbidity; and a lower number of large carnivorous fish (Potter et al., 1986; Whitfield, 1999; Beck et al., 2001; Spach et al., 2003; Hajisamae et al., 2006; Paiva et al., 2008).

One of the primary bases for understanding fish assemblages is the knowledge of their distribution and abundance and their relationship with abiotic factors (Inoue et al., 2008), as well as factors that will limit or affect a change in population (Levin et al., 1997). Several studies from different regions have emphasized abiotic factors, such as temperature and salinity (Harrison \& Whitfield, 2006), salinity and turbidity (Cyrus \& Blaber, 1992; Barletta et al., 2005), turbidity (Cyrus \& Blaber, 1987; Abou-Seedo et al., 1990), morphodynamic models (Inui et al., 2010), and input of freshwater and river flow (Barletta et al., 2005; Vinagre et al., 2009; Baptista et al., 2010; Castillo-Rivera, 2013) as factors that influence the abundance of young fish in these shallow water habitats. Additionally, factors such as recruitment, competition, predation, and structural complexity are listed as ecological processes that determine the structure of these communities, so that the fish assemblages are the result of the complex interaction of abiotic and biotic factors (Mariani, 2001; Laegdsgaard \& Johnson, 2001).

In tropical northeastern Brazilian estuaries, information regarding juvenile fish composition, seasonal variations in abundance, and biomass in shallow water is still largely unavailable. This study aimed to describe the structure and dynamics of fish assemblages on three beaches in the Mamanguape River estuary, and to test the hypothesis that distinct fish assemblages occur along a morphodynamic continuum as the result of changes in environmental variables, particularly the effects of wave action.

\section{Material and Methods}

\section{Study site}

The study was conducted in the Mamanguape River estuary $\left(6^{\circ} 43^{\prime} 02^{\prime \prime} \mathrm{S} 35^{\circ} 67^{\prime} 46^{\prime \prime} \mathrm{W}\right)$, which is the second largest estuary in the state of Paraíba (northeastern Brazil). The estuary is located in an environmental protection area ("EPA") (CERHPB, 2004), whose goal is to protect coastal ecosystems as well as the marine manatee Trichechus manatus Linnaeus, 1758 (Mourão \& Nordi, 2003). The climate is tropical and humid, as its annual total rainfall varies from $2000 \mathrm{~mm}$ to less than $30 \mathrm{~mm}$. Temperatures are high, as the annual average temperature is between $24^{\circ} \mathrm{C}$ and $26^{\circ} \mathrm{C}$ (Macedo et al., 2010). The beaches display a mesotidal, semi-diurnal tidal regime. The mouth of the river forms a 6-km-wide bay that is nearly closed off by a coastal reef line, which results in calm and quiet waters (Paludo \& Klonowski, 1999). In this area, well-preserved mangroves are present that are principally represented by Rhizophora mangle, Avicennia schaueriana, Avicennia germinans, Laguncularia racemosa, and Conocarpus erectus, which grow around the main channel and its intertidal creeks to encompass approximately 6,000 hectares, in addition to the remnants of the Atlantic rainforest (Rocha et al., 2008).

\section{Sampling}

Samples were collected between October 2010 and September 2011, on monthly daytime excursions during spring tides. Sampling was performed at three sites defined according to their locations relative to the mouth of the river (Fig. 1): Curva do Pontal Beach (CPO) (6 $6^{\circ} 46^{\prime} 27^{\prime}$ 'S 34 55'20”W ), which is situated in a protected estuarine region, and presents predominantly muddy sediment, calm waters and seagrass meadows; Pontal Beach (PON) (6 $\left.6^{\circ} 46^{\prime} 22^{\prime \prime} \mathrm{S} 34^{\circ} 55^{\prime} 07^{\prime} \mathrm{W}\right)$, situated beyond the mouth of Mamanguape River, with sandy sediment and a barrier reef parallel to the shoreline which absorbs most of the wave energy; and Campina Beach (CAM) (648'43”S 345' $49^{\circ}$ 'W), which presents sandy sediment, gravels and high wave energy.

The fish were sampled using a beach seine net $(10 \mathrm{~m} \mathrm{x}$ $1.5 \mathrm{~m}$, with an $8-\mathrm{mm}$ mesh). The seine hauls were $30 \mathrm{~m}$ long, parallel to and close to the shore, and were taken out to a depth of approximately $1.5 \mathrm{~m}$. This procedure was replicated five times at each site, separated $5 \mathrm{~m}$ apart to minimize the influence on the following haul. The fish collected were fixed in $10 \%$ formalin and later identified (Figueiredo \& Menezes, 1978, 1980, 2000; Menezes \& Figueiredo, 1980, 1985; Araujo et al., 2004), counted, measured (total length in $\mathrm{mm}$ ), and weighed (g).

For each sample, environmental factors such as water temperature, salinity and transparency were also measured five times at each site, using a mercury thermometer, an optical refractometer and a Secchi disc, respectively. Samples from the sediment were collected in at each beach in five replicates. Granulometric analysis was performed according to Embrapa (1997), with the method using a combination of sieving and sedimentation steps and is designed to be used in conjunction with analysis of particulate organic matter (POM). Wave height and wave period were measured by visually estimating the height of the breaker waves during one minute for three times and the time interval between five successive breaker waves was recorded. 


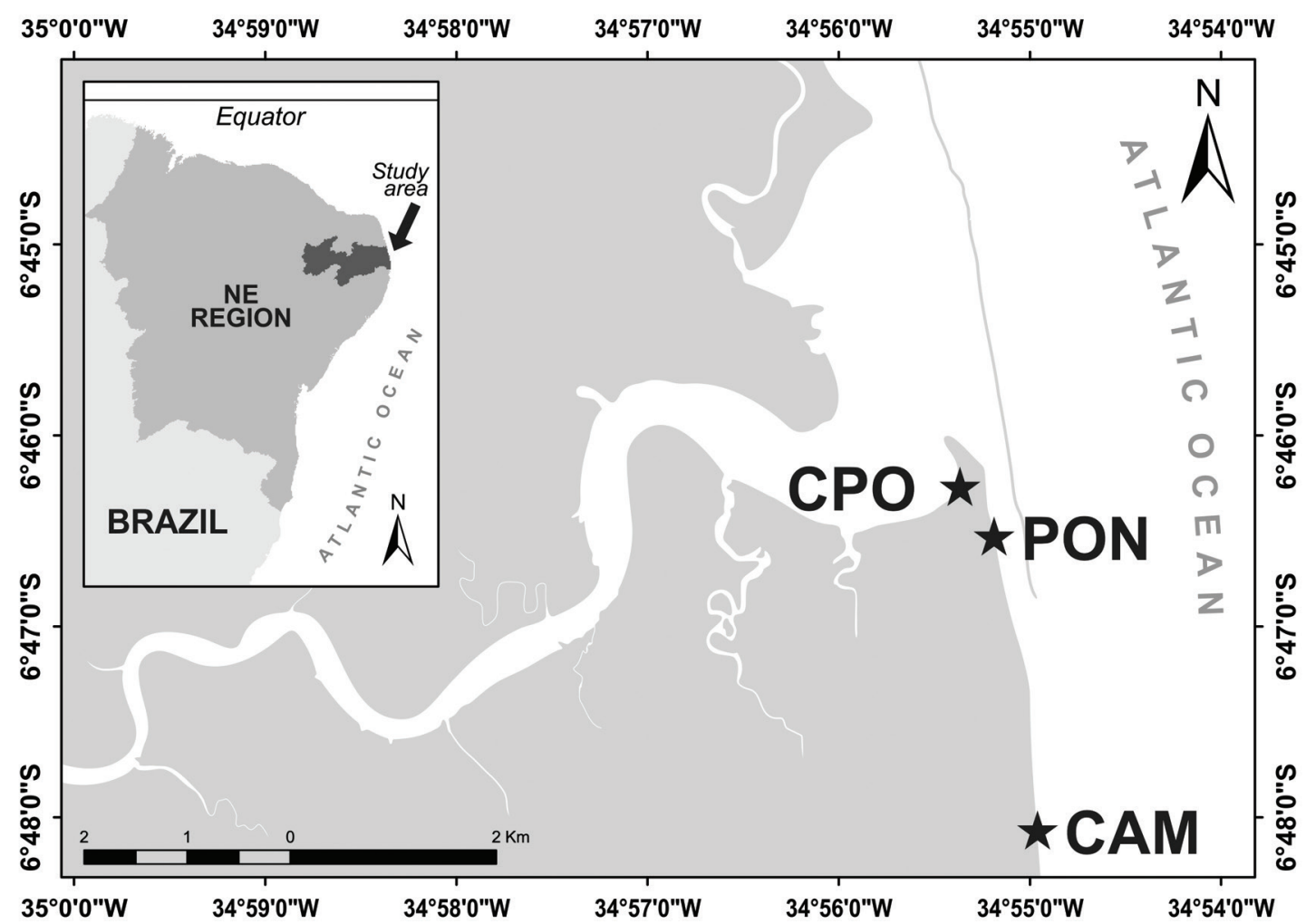

Fig. 1. Map of Mamanguape River estuary with locations of the sampling sites: CPO, Curva do Pontal Beach; PON, Pontal Beach; and CAM, Campina Beach.

\section{Data analysis}

The morphological classification of beaches was performed according to the RTR (Relative Tide Range), which takes into account the average variation of tides and the wave height, whose reference values are: $3<\mathrm{RTR}<7$ : group III (reflective state); $7<$ RTR $<15$ : group II (intermediate state); RTR $>15$ (dissipative state) (Masselink 1993; Calliari et al., 2003).

The environmental variables and the fish abundance (weight and number) were transformed $\left(\log _{10} \mathrm{x}+1\right)$ to meet the assumptions of normality and homoscedasticity prior to comparison using one-way analysis of variance (ANOVA). Analyses were used for spatial comparison between abundance and environmental variables. A post hoc comparison of means was performed using the Tukey HSD test (Zar, 1982).

The data matrix to be analysed via multivariate techniques was created from the numerical abundance data for the species, using the Bray-Curtis similarity coefficient as a measure. An ANOSIM was used to test for differences in fish assemblage structure between beaches. When the ANOSIM test comparisons detected a significant difference, SIMPER was used to identify the species that were related to each beach type. These analyses were undertaken using PRIMER 6.0® statistical software.

Influences of environmental variables on fish assemblages were analysed using Canonical Correspondence Analysis
(CCA), and the results were tested with the Monte Carlo test with 499 permutations. Direct analysis of the gradients through CCA clarified the role that environmental factors play in the structuring of fish assemblage by comparing species composition between sampling sites. A forward selection procedure was performed to identify variables that accounted for the greatest variation. The significance of these variables, defined as $\mathrm{p}<0.05$, was tested in Monte Carlo simulations. The Monte Carlo permutation test, at $\alpha=0.05$, was also used to test the statistical significance of the relationship between species and environmental variables. The software used to perform the analyses was $\mathrm{CANOCO}{ }^{\circledR}$ for Windows.

\section{Results}

\section{Environmental factors}

The RTR varied between 4.40 and 21.11, and according to the morphodynamic classification, where Pontal Beach $(\mathrm{PON})$ fell within the Intermediate beach $(\mathrm{RTR}=8.73)$, while Campina Beach (CAM) was characterized within the Reflective beach $(\mathrm{RTR}=4.40)$. Although being classified as a Dissipative beach (RTR $>15)$, Curva do Pontal Beach (CPO) was dominated by the tide that transition to a tidal flat, and was thus classified as estuarine. 
Table 1. Results from ANOVA for comparisons of abiotic (temperature, salinity and transparency) and biotic (CPUE, Species number and Biomass) factors between beaches and hydrological regime in the Mamanguape River estuary, Brazil. **, $\mathrm{p}<0.01 ; \mathrm{ns}$, not significant.

\begin{tabular}{lcc}
\hline & $\mathrm{F}$ & Tukey \\
\hline Temperature & $\mathrm{ns}$ & - \\
Salinity & $6.88^{* *}$ & Reflective $>$ Dissipative \\
Transparency & $14.27^{* *}$ & Dissipative $>$ Reflective \\
Abundance (CPUE) & $43.745^{* *}$ & Dissipative $>$ Intermediate, Reflective \\
Species number & $39.705^{* *}$ & Dissipative $>$ Intermediate, Reflective \\
Biomass & $36.801^{* *}$ & Dissipative $>$ Intermediate, Reflective \\
\hline
\end{tabular}

Spatially, no significant differences were found for temperature among the beaches. Highest salinity levels were recorded at Reflective Beach (41.3 \pm 0.3$)$ and lowest at Dissipative Beach (11.3 \pm 0.9 ), the highest transparency values were found at Dissipative Beach (99.0 \pm 10.6$)$ and lowest at Reflective Beach (10.0 0 .6). The results were significantly different (Table 1).

\section{Structure and composition}

In total, 3,732 individuals belonging to 71 species (27 families) were collected during 174 beach seine hauls at beaches in the Mamanguape River estuary during the study period (Table 2). The family Carangidae had the largest number of species (7), followed by Sciaenidae (6) and Engraulidae, Gerreidae, Gobiidae, and Tetraodontidae (each with 5). The families with the highest number of individuals were Clupeidae, Atherinopsidae, Engraulidae, and Mugilidae, which collectively represented $79 \%$ of the total number of fish. The families Tetraodontidae, Clupeidae, Atherinopsidae, and Engraulidae, in decreasing order, contributed the most to the weight frequency and accounted for $73 \%$ of the total weight of the fish. Bahia sprat herring Rhinosardinia bahiensis (Steindachner, 1879) contributed the most to numerical abundance, as it accounted for $32 \%$ of the total, followed by the Brazilian silverside, Atherinella brasiliensis (Quoy $\&$ Gaimard, 1825), which represented $16 \%$ of the total abundance. The highest biomass contribution was from the puffer fish Sphoeroides testudineus (Linnaeus, 1758) which contributed $29 \%$ of the total biomass. Among the species, 18 occurred only once in the samples and 7 accounted for less than $0.01 \%$ of the biomass.

The families with the highest number of individuals in the dissipative beach were Clupeidae, Atherinopsidae, Engraulidae, and Mugilidae ( $81 \%$ of total number of individuals). In the intermediary beach, Engraulidae, Clupeidae, Haemulidae, Carangidae, and Sciaenidae were the abundant families (75\%), whereas in the reflective beach,
Engraulidae, Clupeidae, Haemulidae, Carangidae, and Sciaenidae were the most abundant families (96\%).

The species that accounted for the majority of the total number of individuals in each beach were: $R$. bahiensis, $A$. brasiliensis, Lycengraulis grossidens (Agassiz, 1829) and Mugil liza Valenciennes, 1836 in dissipative beach, comprising 74\% of the total number of individuals; L. grossidens, Lile piquitinga (Schreiner \& Miranda Ribeiro, 1903), Anchoa januaria (Steindachner, 1879), Polydactilus virginicus (Linnaeus, 1758) and Anchoviella lepidentostole (Fowler, 1911) in the intermediate beach (51\%); and M. liza, L. grossidens, Mugil gaimardianus Desmarest, 1831 and Trachinotus carolinus (Linnaeus, 1766) in the reflective beach (80\%).

The analysis of the fish assemblages at the three beaches showed that there was a higher abundance, biomass and richness in the dissipative beach than at reflective and intermediary beaches, which demonstrates a significant increase at the site with the lowest exposure to wave activity (Fig. 3). This spatial difference was significant as determined by ANOSIM (Global $\mathrm{R}=0.431 ; \mathrm{P}>0.1$ ), with the dissipative beach being different from intermediary (Global $\mathrm{R}=0.495$;

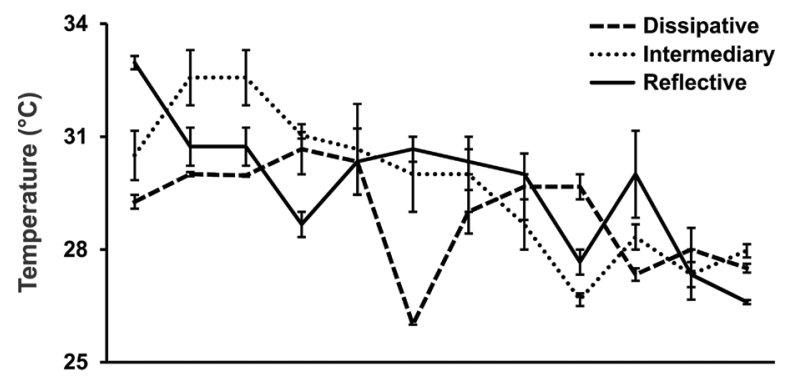

(a)

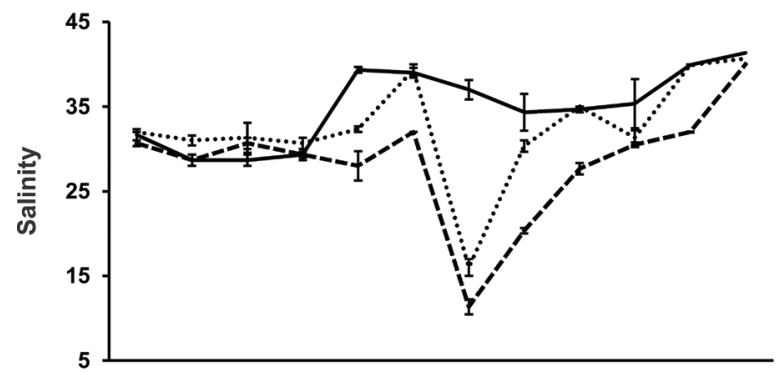

(b)

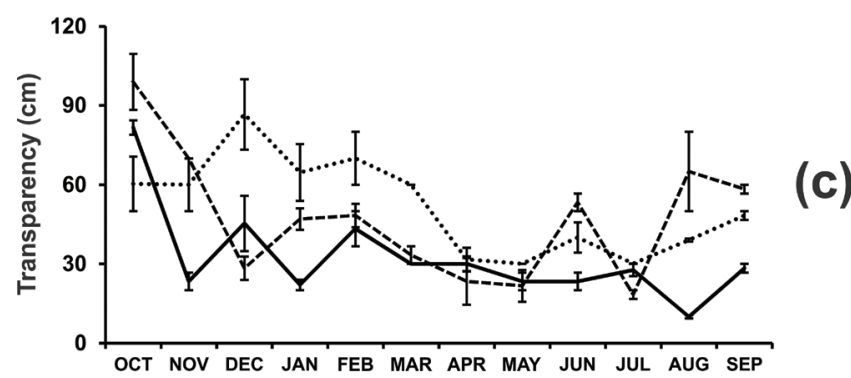

Fig. 2. Mean monthly variations of the environmental variables $( \pm$ SE) for the study period. 

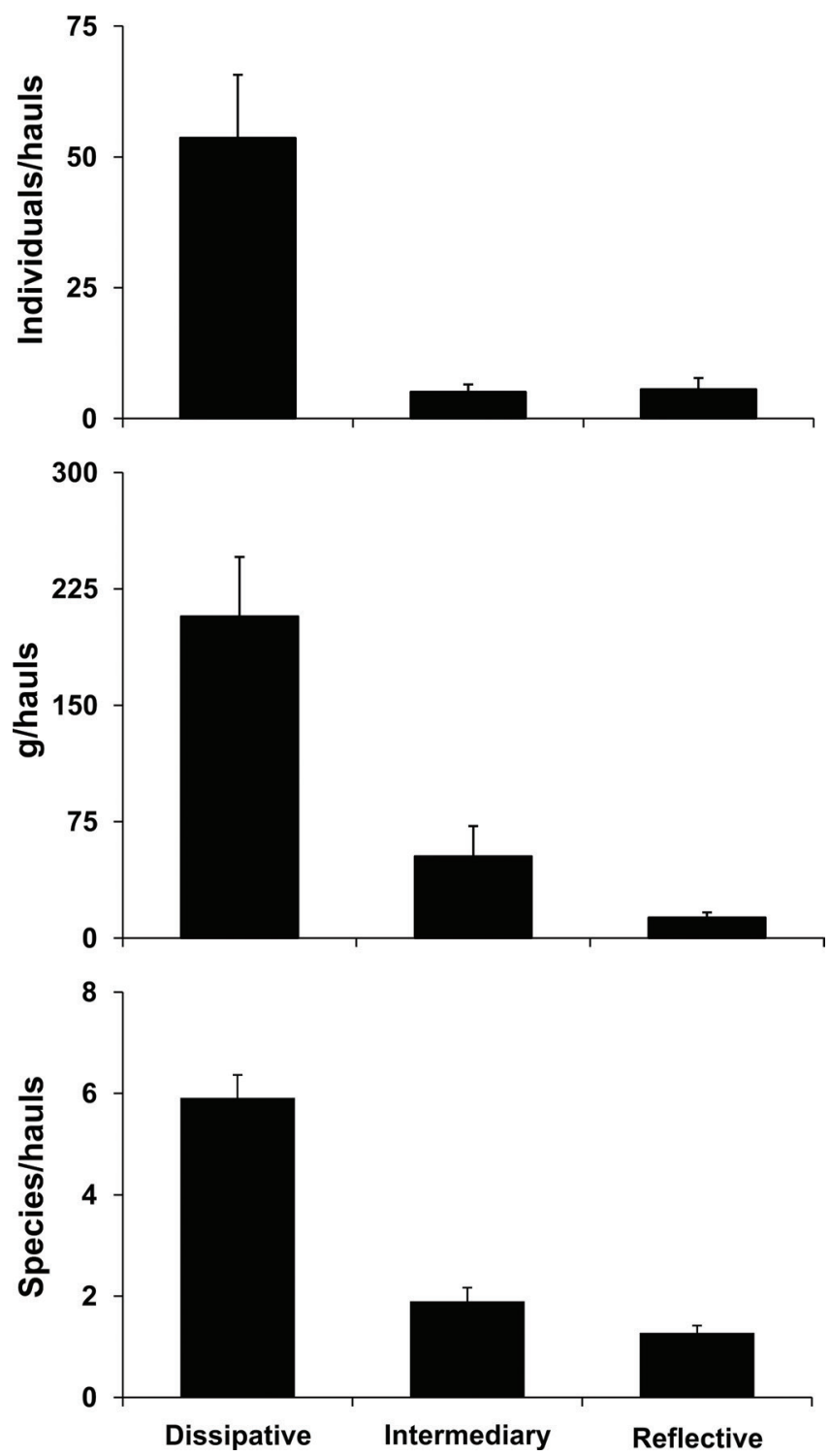

Fig. 3. Variation in the mean number of individuals (CPUE average \pm SE), biomass $( \pm$ SE) and number of species $( \pm$ SE) at Mamanguape River estuary in Brazil.

$\mathrm{P}>0.1$ ) and reflective (Global $\mathrm{R}=0.747 ; \mathrm{P}>0.1$ ) beaches. SIMPER showed higher contributions from L. grossidens, $R$. bahiensis, A. brasiliensis, S. testudineus, and Hyporhamphus unifasciatus (Ranzani, 1841) for dissipative beach, whereas T. carolinus, Trachinotus goodei Jordan and Evermann, 1896, $M$. liza and $P$. virginicus showed higher contributions for intermediary and reflective beaches.

\section{Influence of environmental factors}

The first two axes from canonical correspondence analysis accounted for $63.1 \%$ of the cumulative percentage of variance for the environmental-species relationship (Fig. 4), with the
Monte Carlo analysis revealing that RTR and characteristics of sediment (percentage of sand, silt, and clay) contributed most to species distribution. Samples representing the beaches were separated along the first axis. Axis 1 was positively correlated with RTR and silt clay, and negatively correlated with sand. Axis 2 was negatively correlated with salinity (Table 3).

The species Atherinella blackburni (Schultz, 1949), T. carolinus, Mugil hospes Jordan \& Culver, 1895, M. liza, T. goodei, Menticirrhus littoralis (Holbrook, 1847), and $L$. grossidens were associated with sandy bottoms and higher salinity, conditions of the reflective beaches. A considerable amount of species (such as Achirus lineatus, Citharichthys spilopterus, Citharichthys macrops Dresel, 1885, Gobionellus stomatus Starks, 1913, R. bahiensis and others) was influenced by high values of RTR, silt and clay, suggesting a preference for dissipative beaches (Figure 4).

\section{Discussion}

Spatial differences in the structure for fish assemblages was demonstrated among the three tropical beaches that are strongly influenced by wave action, which is thought by many authors to be synonymous with exposure. This heterogeneous spatial distribution pattern of fish species showed a higher abundance, biomass and richness for the estuarine beach compared with the reflective beach with different species being characteristics of each beaches. These observations corroborate the hypothesis that the degree of exposure is a primary factor shaping local assemblages of fishes. This pattern has been demonstrated in other studies in tropical and subtropical regions (Romer, 1990; Clark, 1997; Jovanovic et al., 2007, Vasconcellos et al., 2007).

Estuarine beaches, which are also called "low energy" beaches, differ from the most exposed beaches in having additional features such as a narrow and abrupt sandy upper beach portion, a marked break in profile and a broad coastal plain with a smooth gradient (Rosa \& Borzone, 2008). In estuarine beaches, the high fish abundance observed results from the aggregation of Clupeiforms species (such as $R$. bahiensis, A. clupeioides (Swainson, 1839), and L. grossidens in this study). Therefore, these beaches have been considered to be recruitment areas during the life cycles of these species (Oliveira-Silva et al., 2008; Hackradt et al., 2009). Moreover, the aggregation serves as a temporary refuge in calmer habitats close to the coast because high-energy sites do not permit such behaviour, mainly because of the high dynamic of the water column, which potentially results in high energy consumption (Felix et al., 2007). The use of calmer sites, such as those inside of bays and estuaries (Blaber \& Blaber, 1980; Pessanha \& Araújo, 2003) and even sheltered sandy beaches (Barreiros et al., 2004), plays an important recruitment role for pelagic species. 
Table 2. Numerical abundance, biomass, frequency of occurrence, spatial distribution and maximum and minimum length of fish species captured on three beaches in the Mamanguape River estuary of Brazil. The species are ordered in accordance with Nelson (2006).

\begin{tabular}{|c|c|c|c|c|c|c|c|c|c|c|c|c|}
\hline \multirow[b]{2}{*}{ Family } & \multirow[b]{2}{*}{ Species } & \multirow[b]{2}{*}{ Code } & \multicolumn{2}{|c|}{$\begin{array}{c}\text { Total } \\
\text { abundance }\end{array}$} & \multicolumn{2}{|c|}{ Total biomass } & \multirow{2}{*}{$\% \mathrm{OF}$} & \multicolumn{3}{|c|}{ Spatial distribution } & \multicolumn{2}{|c|}{$\begin{array}{l}\text { Length } \\
(\mathrm{mm})\end{array}$} \\
\hline & & & $\mathrm{N}$ & $\%$ & $\mathrm{~W}(\mathrm{~g})$ & $\%$ & & $\mathrm{CPO}$ & PON & CAM & $\mathrm{L}_{\min }$ & $\mathrm{L}_{\max }$ \\
\hline \multirow[t]{5}{*}{ Engraulidae } & Anchoa januaria (Steindachner, 1879) & ANJA & 30 & 0.8 & 24.47 & 0.15 & 4.02 & $\mathrm{X}$ & $\mathrm{X}$ & & 48 & 62 \\
\hline & Anchovia clupeoides (Swainson, 1839) & ANCL & 69 & 1.85 & 405.77 & 2.56 & 5.17 & $\mathrm{X}$ & $\mathrm{X}$ & & 50 & 134 \\
\hline & Anchoviella lepidentostole (Fowler, 1911) & ANLE & 58 & 1.55 & 105.59 & 0.67 & 4.02 & $\mathrm{X}$ & $\mathrm{X}$ & & 38 & 122 \\
\hline & Cetengraulis edentulus (Cuvier, 1829) & CEED & 2 & 0.05 & 17.55 & 0.11 & 1.15 & $\mathrm{X}$ & $\mathrm{X}$ & & 63 & 120 \\
\hline & Lycengraulis grossidens (Agassiz, 1829) & LYGR & 428 & 11.47 & 624.43 & 3.95 & 22.99 & $\mathrm{X}$ & $\mathrm{X}$ & $\mathrm{X}$ & 31 & 110 \\
\hline \multirow[t]{4}{*}{ Clupeidae } & Harengula clupeola (Cuvier, 1829) & HACL & 17 & 0.46 & 56.28 & 0.36 & 2.3 & $\mathrm{X}$ & & & 60 & 96 \\
\hline & $\begin{array}{l}\text { Lile piquitinga (Schreiner \& Miranda } \\
\text { Ribeiro, 1903) }\end{array}$ & LIPI & 33 & 0.88 & 224.76 & 1.42 & 3.45 & $\mathrm{X}$ & $\mathrm{X}$ & & 74 & 114 \\
\hline & Opisthonema oglinum (Lesueur, 1818) & OPOG & 14 & 0.38 & 301.88 & 1.91 & 0.57 & & $\mathrm{X}$ & & 99 & 154 \\
\hline & $\begin{array}{l}\text { Rhinosardinia bahiensis (Steindachner, } \\
\text { 1879) }\end{array}$ & RHBA & 1204 & 32.26 & 2781.05 & 17.57 & 9.77 & $\mathrm{X}$ & $\mathrm{X}$ & & 24 & 106 \\
\hline Ariidae & Sciades herzbergii (Bloch, 1794) & SCHE & 2 & 0.05 & 7.43 & 0.05 & 0.57 & & $\mathrm{X}$ & & 65 & 73 \\
\hline Batrachoididae & $\begin{array}{l}\text { Thalassophryne nattereri Steindachner, } \\
1876\end{array}$ & THNA & 1 & 0.03 & 7.59 & 0.05 & 0.57 & $\mathrm{X}$ & & & 79 & - \\
\hline \multirow[t]{4}{*}{ Mugilidae } & Mugil curema Valenciennes, 1836 & MUCU & 17 & 0.46 & 93.8 & 0.59 & 2.87 & $\mathrm{X}$ & $\mathrm{X}$ & & 46 & 110 \\
\hline & Mugil hospes Jordan \& Culver, 1895 & MUHO & 101 & 2.71 & 146.96 & 0.93 & 5.75 & $\mathrm{X}$ & $\mathrm{X}$ & $\mathrm{X}$ & 27 & 95 \\
\hline & Mugil incilis Hancock, 1830 & MUIN & 1 & 0.03 & 4.53 & 0.03 & 0.57 & $\mathrm{X}$ & & & 82 & - \\
\hline & Mugil liza Valenciennes, 1836 & MULI & 371 & 9.94 & 108.55 & 0.69 & 15.52 & $\mathrm{X}$ & $\mathrm{X}$ & $\mathrm{X}$ & 17 & 39 \\
\hline \multirow[t]{2}{*}{ Atherinopsidae } & Atherinella blackburni (Schultz, 1949) & ATBL & 7 & 0.19 & 38.14 & 0.24 & 3.45 & & & $\mathrm{X}$ & 90 & 104 \\
\hline & $\begin{array}{l}\text { Atherinella brasiliensis (Quoy \& Gaimard, } \\
\text { 1825) }\end{array}$ & ATBR & 601 & 16.1 & 1764.6 & 11.15 & 22.99 & $\mathrm{X}$ & $\mathrm{X}$ & & 17 & 127 \\
\hline Hemiramphidae & $\begin{array}{l}\text { Hyporhamphus unifasciatus (Ranzani, } \\
\text { 1841) }\end{array}$ & HYUN & 83 & 2.22 & 631.61 & 3.99 & 9.77 & $\mathrm{X}$ & $\mathrm{X}$ & & 81 & 202 \\
\hline Belonidae & Strongylura timucu (Walbaum, 1792) & STTI & 1 & 0.03 & 0.06 & $<0.01$ & 0.57 & $\mathrm{X}$ & & & 43 & - \\
\hline Syngnathidae & Syngnathus folletti Herald, 1942 & SYFO & 1 & 0.03 & 0.11 & $<0.01$ & 0.57 & & $\mathrm{X}$ & & 110 & - \\
\hline Dactylopteridae & Dactylopterus volitans (Linnaeus, 1758) & DAVO & 2 & 0.05 & 8.38 & 0.05 & 1.15 & $\mathrm{X}$ & & & 60 & - \\
\hline \multirow[t]{2}{*}{ Centropomidae } & Centropomus parallelus Poey, 1860 & CEPA & 1 & 0.03 & 20.76 & 0.13 & 0.57 & $\mathrm{X}$ & & & 52 & - \\
\hline & Centropomus undecimalis (Bloch, 1792) & CEUN & 1 & 0.03 & 83.64 & 0.53 & 0.57 & & & $\mathrm{X}$ & 220 & - \\
\hline Serranidae & $\begin{array}{l}\text { Diplectrum radiale (Quoy \& Gaimard, } \\
\text { 1824) }\end{array}$ & DIRA & 1 & 0.03 & 1.03 & 0.01 & 0.57 & & $\mathrm{X}$ & & 46 & - \\
\hline \multirow[t]{7}{*}{ Carangidae } & Caranx latus Agassiz, 1831 & CALA & 46 & 1.23 & 186.86 & 1.18 & 9.2 & $\mathrm{X}$ & $\mathrm{X}$ & $\mathrm{X}$ & 26 & 95 \\
\hline & $\begin{array}{l}\text { Chloroscombrus chrysurus (Linnaeus, } \\
1766 \text { ) }\end{array}$ & $\mathrm{CLCH}$ & 1 & 0.03 & 0.23 & $<0.01$ & 0.57 & & $\mathrm{X}$ & & 28 & - \\
\hline & $\begin{array}{l}\text { Oligoplites saurus (Bloch \& Schneider, } \\
\text { 1801) }\end{array}$ & OLSA & 15 & 0.4 & 30.96 & 0.2 & 6.32 & $\mathrm{X}$ & $\mathrm{X}$ & & 31 & 102 \\
\hline & Selene setapinnis (Mitchill, 1815) & SESE & 1 & 0.03 & 0.29 & $<0.01$ & 0.57 & & $\mathrm{X}$ & & 25 & - \\
\hline & Trachinotus carolinus (Linnaeus, 1766) & TRCA & 35 & 0.94 & 87.52 & 0.55 & 9.2 & & $\mathrm{X}$ & $\mathrm{X}$ & 15 & 87 \\
\hline & Trachinotus falcatus (Linnaeus, 1758) & TRFA & 6 & 0.16 & 17.76 & 0.11 & 2.3 & $\mathrm{X}$ & $\mathrm{X}$ & $\mathrm{X}$ & 42 & 86 \\
\hline & $\begin{array}{l}\text { Trachinotus goodei Jordan \& Evermann, } \\
1896\end{array}$ & TRGO & 31 & 0.83 & 265.56 & 1.68 & 9.77 & & $\mathrm{X}$ & $\mathrm{X}$ & 18 & 153 \\
\hline Lutjanidae & Lutjanus synagris (Linnaeus, 1758) & LUSY & 17 & 0.46 & 241.32 & 1.52 & 4.6 & $\mathrm{X}$ & & & 27 & 157 \\
\hline \multirow[t]{3}{*}{ Gerreidae } & Diapterus rhombeus (Cuvier, 1829) & DIRH & 4 & 0.11 & 35.71 & 0.23 & 1.72 & $\mathrm{X}$ & & & 43 & 115 \\
\hline & $\begin{array}{l}\text { Eucinostomus argenteus Girard \& Baird, } \\
1855\end{array}$ & EUAR & 62 & 1.66 & 137.4 & 0.87 & 6.9 & $\mathrm{X}$ & & & 10 & 105 \\
\hline & $\begin{array}{l}\text { Eucinostomus gula (Quoy \& Gaimard, } \\
\text { 1824) }\end{array}$ & EUGU & 3 & 0.08 & 26.85 & 0.17 & 1.72 & $\mathrm{X}$ & & & 65 & 112 \\
\hline
\end{tabular}


Table 2. Cont. Numerical abundance, biomass, frequency of occurrence, spatial distribution and maximum and minimum length of fish species captured on three beaches in the Mamanguape River estuary of Brazil. The species are ordered in accordance with Nelson (2006).

\begin{tabular}{|c|c|c|c|c|c|c|c|c|c|c|c|c|}
\hline & $\begin{array}{l}\text { Eucinostomus melanopterus (Bleeker, } \\
1863 \text { ) }\end{array}$ & EUME & 35 & 0.94 & 13.75 & 0.09 & 5.17 & $\mathrm{X}$ & & & 15 & 68 \\
\hline & Eugerres brasilianus (Cuvier, 1830) & EUBR & 13 & 0.35 & 43.18 & 0.27 & 5.17 & $\mathrm{X}$ & & & 26 & 99 \\
\hline \multirow[t]{4}{*}{ Haemulidae } & Conodon nobilis (Linnaeus, 1758) & CONO & 20 & 0.54 & 123.43 & 0.78 & 1.15 & & $\mathrm{X}$ & $\mathrm{X}$ & 25 & 100 \\
\hline & $\begin{array}{l}\text { Pomadasys corvinaeformis (Steindachner, } \\
1868 \text { ) }\end{array}$ & POCO & 12 & 0.32 & 365.03 & 2.31 & 2.3 & $\mathrm{X}$ & $\mathrm{X}$ & & 59 & 165 \\
\hline & Pomadasys crocro (Cuvier, 1830) & POCR & 5 & 0.13 & 3.23 & 0.02 & 0.57 & & $\mathrm{X}$ & & 30 & 46 \\
\hline & Pomadasys ramosus (Poey, 1860) & PORA & 4 & 0.11 & 67.67 & 0.43 & 1.15 & $\mathrm{X}$ & $\mathrm{X}$ & & 72 & 77 \\
\hline Polynemidae & Polydactylus virginicus (Linnaeus, 1758) & POVI & 28 & 0.75 & 122.63 & 0.77 & 9.77 & & $\mathrm{X}$ & $\mathrm{X}$ & & \\
\hline \multirow[t]{6}{*}{ Sciaenidae } & Bairdiella ronchus (Cuvier, 1830) & BARO & 1 & 0.03 & 15.38 & 0.1 & 0.57 & & $\mathrm{X}$ & & 110 & - \\
\hline & $\begin{array}{l}\text { Menticirrhus americanus (Linnaeus, } \\
1758 \text { ) }\end{array}$ & MEAM & 2 & 0.05 & 85.59 & 0.54 & 1.15 & & $\mathrm{X}$ & $\mathrm{X}$ & 126 & 193 \\
\hline & Menticirrhus littoralis (Holbrook, 1847) & MELI & 24 & 0.64 & 352.47 & 2.23 & 10.92 & $\mathrm{X}$ & $\mathrm{X}$ & $\mathrm{X}$ & 34 & 236 \\
\hline & Pogonias cromis (Linnaeus, 1766) & POCM & 1 & 0.03 & 0.64 & $<0.01$ & 0.57 & & $\mathrm{X}$ & & 36 & - \\
\hline & Stellifer brasiliensis (Schultz, 1945) & STBR & 4 & 0.11 & 17.73 & 0.11 & 1.15 & & $\mathrm{X}$ & & 33 & 104 \\
\hline & Stellifer naso (Jordan, 1889) & STNA & 1 & 0.03 & 5.14 & 0.03 & 0.57 & & $\mathrm{X}$ & & 75 & - \\
\hline Eleotridae & Erotelis smaragdus (Valenciennes, 1837) & ERSM & 9 & 0.24 & 14.06 & 0.09 & 4.02 & $\mathrm{X}$ & $\mathrm{X}$ & & 14 & 85 \\
\hline \multirow[t]{5}{*}{ Gobiidae } & $\begin{array}{l}\text { Bathygobius soporator (Valenciennes, } \\
\text { 1837) }\end{array}$ & BASO & 22 & 0.59 & 192.5 & 1.22 & 9.2 & $\mathrm{X}$ & & & 88 & 124 \\
\hline & $\begin{array}{l}\text { Ctenogobius boleosoma (Jordan \& } \\
\text { Gilbert, 1882) }\end{array}$ & СТВО & 22 & 0.59 & 6.13 & 0.04 & 4.6 & $\mathrm{X}$ & & & 26 & 52 \\
\hline & $\begin{array}{l}\text { Ctenogobius smaragdus (Valenciennes, } \\
1837 \text { ) }\end{array}$ & CTSM & 11 & 0.29 & 17.27 & 0.11 & 4.6 & $\mathrm{X}$ & & & 24 & 92 \\
\hline & Ctenogobius stigmaticus (Poey, 1860) & CTST & 7 & 0.19 & 0.69 & $<0.01$ & 2.3 & $\mathrm{X}$ & & & 22 & 33 \\
\hline & Gobionellus stomatus Starks, 1913 & GOST & 12 & 0.32 & 8.73 & 0.06 & 4.6 & $\mathrm{X}$ & & & 30 & 93 \\
\hline Acanthuridae & Acanthurus bahianus Castelnau, 1855 & ACBA & 1 & 0.03 & 1 & 0.01 & 0.57 & $\mathrm{X}$ & & & 38 & - \\
\hline Scombridae & $\begin{array}{l}\text { Scomberomorus brasiliensis Collette, } \\
\text { Russo \& Zavala-Camin, } 1978\end{array}$ & SCBR & 1 & 0.03 & 2.96 & 0.02 & 0.57 & $\mathrm{X}$ & & & 83 & - \\
\hline \multirow[t]{4}{*}{ Paralichthyidae } & $\begin{array}{l}\text { Citharichthys arenaceus Evermann \& } \\
\text { Marsh, } 1900\end{array}$ & CIAR & 6 & 0.16 & 57.08 & 0.36 & 2.87 & $\mathrm{X}$ & $\mathrm{X}$ & & 76 & 94 \\
\hline & Citharichthys macrops Dresel, 1885 & CIMA & 42 & 1.13 & 81.04 & 0.51 & 7.47 & $\mathrm{X}$ & & & 18 & 140 \\
\hline & Citharichthys spilopterus Günther, 1862 & CISP & 23 & 0.62 & 124.8 & 0.79 & 5.75 & $\mathrm{X}$ & & & 52 & 121 \\
\hline & Etropus crossotus Jordan \& Gilbert, 1882 & ETCR & 1 & 0.03 & 0.1 & $<0.01$ & 0.57 & & $\mathrm{X}$ & & 25 & - \\
\hline \multirow[t]{2}{*}{ Achiridae } & Achirus lineatus (Linnaeus, 1758) & ACLI & 24 & 0.64 & 69.81 & 0.44 & 4.6 & $\mathrm{X}$ & & & 15 & 114 \\
\hline & $\begin{array}{l}\text { Trinectes paulistanus (MirandaRibeiro, } \\
\text { 1915) }\end{array}$ & TRPA & 1 & 0.03 & 1.15 & 0.01 & 0.57 & $\mathrm{X}$ & & & 45 & - \\
\hline \multirow[t]{2}{*}{ Cynoglossidae } & $\begin{array}{l}\text { Symphurus plagusia (Bloch \& Schneider, } \\
\text { 1801) }\end{array}$ & SYPL & 7 & 0.19 & 126.89 & 0.8 & 2.87 & $\mathrm{X}$ & & & 113 & 171 \\
\hline & $\begin{array}{l}\text { Symphurus tessellatus (Quoy \& Gaimard, } \\
1824 \text { ) }\end{array}$ & SYTE & 19 & 0.51 & 159.54 & 1.01 & 4.6 & $\mathrm{X}$ & & & 39 & 153 \\
\hline \multirow[t]{5}{*}{ Tetraodontidae } & Lagocephalus laevigatus (Linnaeus, 1766) & LALA & 1 & 0.03 & 402.32 & 2.54 & 0.57 & & $\mathrm{X}$ & & 283 & - \\
\hline & Sphoeroides greeleyi Gilbert, 1900 & SPGR & 11 & 0.29 & 142.84 & 0.9 & 4.02 & $\mathrm{X}$ & & & 39 & 105 \\
\hline & Sphoeroides spengleri (Bloch, 1785) & SPSP & 8 & 0.21 & 46.37 & 0.29 & 3.45 & $\mathrm{X}$ & & & 23 & 74 \\
\hline & Sphoeroides testudineus (Linnaeus, 1758) & SPTE & 81 & 2.17 & 4658.1 & 29.43 & 18.97 & $\mathrm{X}$ & $\mathrm{X}$ & & 12 & 236 \\
\hline & Sphoeroides tyleri Shipp, 1972 & SPTY & 1 & 0.03 & 1.24 & 0.01 & 0.57 & $\mathrm{X}$ & & & 38 & - \\
\hline Diodontidae & $\begin{array}{l}\text { Chilomycterus antillarum Jordan \& } \\
\text { Rutter, } 1897\end{array}$ & CHAN & 2 & 0.05 & 2.81 & 0.02 & 1.15 & $\mathrm{X}$ & $\mathrm{X}$ & & 33 & - \\
\hline
\end{tabular}




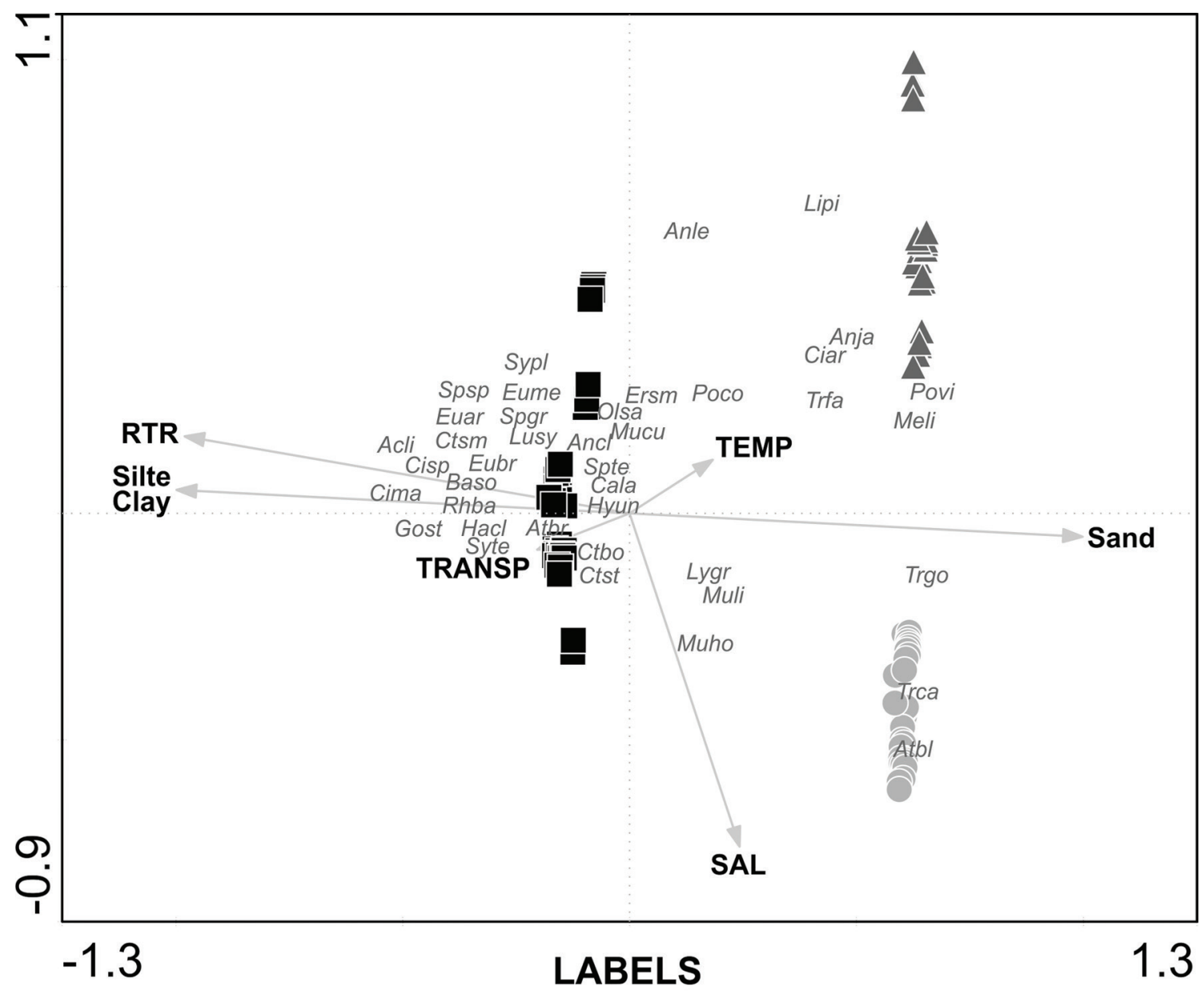

\section{Dissipative Beach}

Intermediary Beach

Reflective Beach

Fig. 4. Ordination diagram (tripolot) from Canonical Correspondence Analysis for the numerical abundance of fish species and environmental variables. $(\mathrm{TEMP}=$ Temperature; $\mathrm{SAL}=$ Salinity; TRANSP $=$ Transparency and $\mathrm{RTR}=$ Relative Tide Range). (Acli = Achirus lineatus; Ancl = Anchovia clupeoides; Anja = Anchoa januaria $;$ Anle = Anchoviella lepidentostole; Atbl $=$ Atherinella blackburni $;$ Atbr $=$ Atherinella brasiliensis $;$ Baso $=$ Bathygobius soporator $;$ Cala $=$ Caranx latus $;$ Ciar $=$ Citharichthys arenaceus; $\mathrm{Cima}=$ Citharichthys macrops; $\mathrm{Cisp}=$ Citharichthys spilopterus; Ctbo $=$ Ctenogobius boleosoma; Ctsm $=$ Ctenogobius smaragdus; Ctst $=$ Ctenogobius stigmaticus; Ersm $=$ Erotelis smaragdus; Euar $=$ Eucinostomus argentus; Eubr $=$ Eugerres brasilianus $;$ Eume $=$ Eucinostomus melanopterus $;$ Gost $=$ Gobionellus stomatus $;$ Hacl = Harengula clupeola $;$ Hyun = Hyporhamphus unifasciatus; Lipi = Lile piquitinga $;$ Lusy = Lutjanus synagris; Lygr = Lycengraulis grossidens; Meli = Menticirrhus littoralis; Mucu = Mugil curema $;$ Muho = Mugil hospes; Muli = Mugil liza; Olsa = Oligoplites saurus; Poco $=$ Pomadasys corvinaeformis $;$ Povi = Polydactylus virginicus $;$ Rhba $=$ Rhinosardinia bahiensis $;$ Spgr = Sphoeroides greeleyi; Spsp $=$ Sphoeroides spengleri; Spte $=$ Sphoeroides testudineus $;$ Sypl = Symphurus plagusia $;$ Syte $=$ Symphurus tesselatus; Trca $=$ Trachinotus carolinus; $\operatorname{Trfa}=$ Trachinotus falcatus $;$ Trgo $=$ Trachinotus goodei $)$.

For juvenile and young-of-the-year fishes, beaches located within estuaries provide an ideal site for growth and protection. At these beaches, a constant supply of food has been observed because of the primary production and the absence of large predators (Inui et al., 2010). As species indicative of sheltered environments, S. testudineus (Felix et al., 2007), M. liza (Pessanha \& Araújo, 2003; Vasconcellos et al., 2007) and Bathygobius soporator (Valenciennes, 1837) (Oliveira-Silva et al., 2008) are prominent. Furthermore, the small size of the individuals increases their agility in shallow coastal water and thus increases their success rate when catching suspended prey, as most of the juveniles are zooplanktivorous (Lasiak, 1986; Inoue et al., 2008). These characteristics indicate that estuarine beaches function more effectively than reflective beaches as nursery areas for a larger number of species.

Reflective beach has the lowest abundance and richness among the three studied beaches because of limiting factors such as increased wave energy and the high variability of abiotic factors. The degree of wave exposure is one of the characteristics that contributes most to determine fish 
assemblage structure, with typical of surf zones supporting high numbers of fish species, such as Trachinotus (T. carolinus and T. goodei) (Gomes et al., 2003; McLachlan \& Brown, 2006), Menticirrhus [M. americanus (Linnaeus, 1758) and $M$. littoralis) (Layman, 2000; McLachlan \& Brown, 2006) and Polydactylus (P. virginicus) (Gianinni \& Paiva-Filho, 1995; McLachlan \& Brown, 2006; Oliveira-Silva et al., 2008)]. These species can be considered to be residents of the surf zones of reflective beaches, as indicated by McLachlan \& Brown (2006). Few species can adapt and colonize highly dynamic environments such as the surf zones of reflective beaches (Vasconcellos et al., 2007), although these beaches provide protection from predation and a wide availability of zooplankton for feeding juvenile and larval fish (Lasiak, 1986). Wootton (1992) explains that fish from high-energy zones developed during their evolutionary history appropriate body shapes for minimizing energy costs by effectively counteracting the effects of waves, i.e., a more hydrodynamic form that minimizes the effects of wave energy.

The low number of individuals captured at the intermediate and reflective beaches indicates that these beaches act as nursery areas for a limited number of species. According to Beck et al. (2001), a characteristic that is considered primary for defining nursery areas is their great contribution to the production of individuals that recruit for adult populations. Nonetheless, some studies suggest that selective capture by the net, as well as the difficulty of seine hauling on high-exposure beaches, could influence the low abundance at reflective and intermediate beaches (Romer, 1990; Vasconcelos et al., 2007).

The beaches have functional ecological connections with adjacent ecosystems, such as estuaries and coastal lagoons, and may serve as passage routes and/or habitats, especially for juvenile individuals (Inui et al., 2010). On beaches adjacent to estuaries, the surf zone could provide water masses with low salinity that have been shown to be important in attracting juvenile fish, which are usually recruited within protected environments (Fisher \& Pearcy, 1995). Therefore, the distribution of such species is determined according to a continuиm or environmental gradient (herein represented by the gradual change in the degree of wave exposure along the estuary) where species turnover occurs along gradients of physical conditions, and where there are no well-defined barriers that isolate different communities (Ricklefs, 2003). The occurrence of certain species, such as M. littoralis, $P$. virginicus, and $T$. goodei in reflective and intermediate beaches, and $A$. brasiliensis and L. grossidens through all three beaches, demonstrates that there is connectivity between the beaches and the estuary, which may represent an open community pattern. Among other species that had a significant representation at the reflective beach in this study, M. liza and $M$. hospes are noteworthy because they had a high abundance of juveniles recruited at the estuarine beach, which suggests connectivity between the fish assemblage. This connectivity between beaches and estuarine environments has been described for subtropical environments (Monteiro-Neto et al., 2008) for species of Clupeiformes, and also in a study by Xavier et al. (2012) that observed connectivity between reef systems and mangroves within the same study area.

Results of this study indicate that two factors, namely the RTR and characteristics of sediment, play a major role determining spatial variations in fish abundance and community structure. Some other variables, e.g., salinity and transparency, also play an important role, but are probably of secondary importance. Species-specific preferences for varying combinations of these variables result in variations in the structure and overall abundance of fish assemblages in different areas. Overall, the following trends were observed: the dissipative beaches were found to harbor the most diverse assemblage of fishes, while the reflective beach harbored the lowest densities of fishes.

\section{Acknowledgments}

We wish to thank the members of the Laboratorio de Ecologia de Peixes, Universidade Estadual da Paraíba (UEPB) for their invaluable advice and assistance with fieldwork. We particularly thank Gabriela Figueiredo, Bianca Soares and Nathalia Medeiros, pioneering members of the project in the rio Mamanguape, for their support. Lastly, we thank UEPB for the structural and logistical support provided during the project, as well as for scholarships provided through the Institutional Scholarship Program for Undergraduate Research (PIBIC).

\section{Literature Cited}

Able, K. W. 2005. A re-examination of fish estuarine dependence: Evidence for connectivity between estuarine and ocean habitats. Estuarine, Coastal and Shelf Science, 64: 5-17.

Abou-Seedo, F., D. A. Clayton \& J. M. Wright. 1990. Tidal and turbidity effects on the shallow-water fish assemblage of Kuwait Bay. Marine Ecology Progress Series, 65: 213-223.

Araujo, M. E., J. M. C. Teixeira \& A. M. E. Oliveira. 2004. Peixes estuarinos do nordeste brasileiro: Guia Ilustrado. Recife, Editora Universitária UFPE e EFC.

Barletta, M., A. Barletta-Bergan, U. Saint-Paul \& G. Hubold. 2005. The role of salinity in structuring the fish assemblages in a tropical estuary. Journal of Fish Biology, 66: 45-72.

Baptista, J., F. Martinho, M. Dolbeth, I. Viegas, H. Cabral \& M. Pardal. 2010. Effects of freshwater flow on the fish assemblage of the Mondego estuary (Portugal): comparison between drought and non-drought years. Marine and Freshwater Research, 61: 490-501.

Barreiros, J. P., V. Figna, M. Hostim-Silva \& R. S. Santos. 2004. Seasonal changes in a sandy beach fish assemblage at Canto Grande, Santa Catarina, South Brazil. Journal of Coastal Research, 203: 862-870.

Beck, M. W., K. L. Heck-Jr., K. W. Able, D. L. Childers, D. B. Eggleston, B. M. Gillanders, B. Halpern, C. G. Hays, K. Hoshino, T. J. Minello, R. J. Orth, P. F. Sheridan \& M. 
P. Weinstein. 2001. The identification, conservation, and management of estuarine and marine nurseries for fish and invertebrates. BioScience, 51: 633-641.

Bernabeu, A. M., A. V. Lersundi-Kanpistegi \& F. Vilas. 2012. Gradation from oceanic to estuarine beaches in a ría environment: A case study in the Ría de Vigo. Estuarine, Coastal and Shelf Science, 102-103: 60-69.

Blaber, S. J. M. \& T. G. Blaber. 1980. Factors affecting the distribution of juvenile estuarine and inshore fish. Journal of Fish Biology, 17: 143-162.

Calliari, L. J., D. Muehc, F. G. Hoefel \& E. Toldo-Jr. 2003. Morfodinâmica praial: uma breve revisão. Revista Brasileira de Oceanografia, 51: 63-78.

Castillo-Rivera, M. 2013. Influence of rainfall pattern in the seasonal variation of fish abundance in a tropical estuary with restricted marine communication. Journal of Water Resource and Protection, 5: 311-319.

CERHPB - Conselho Estadual de Recursos Hídricos do Estado da Paraíba. 2004. Proposta de instituição do Comitê das Bacias Hidrográficas do Litoral Norte. AESA, João Pessoa-PB, 78 p. Available from: http://www.aesa.pb.gov.br/comites/litoral_norte/ proposta.pdf

Clark, B. M. 1997. Variation in surf-zone fish community structure across a wave-exposure gradient. Estuarine, Coastal and Shelf Science, 44: 659-674.

Cyrus, D. P. \& S. J. M. Blaber. 1987. The influence of turbidity on juvenile marine fish in the estuaries of Natal, South Africa. Continental Shelf Research, 7: 1411-1416.

Cyrus, D. P. \& S. J. M. Blaber. 1992. Turbidity and salinity in a tropical Northern Australian estuary and their influence on fish distribution. Estuarine, Coastal and Shelf Science, 35: 545-563.

EMBRAPA-Empresa Brasileira de Pesquisa Agropecuária. 1997. Manual de Métodos de Análise de Solo. Rio de Janeiro, Centro Nacional de Pesquisa de Solos.

Félix, F. C., H. L. Spach, P. S. Moro, R. Schwarz-Jr., C. Santos, C. W. Hackradt \& M. Hostim-Silva. 2007. Utilization patterns of surf zone inhabiting fish from beaches in Southern Brazil. Pan-American Journal of Aquatic Sciences, 2: 27-39.

Figueiredo, J. L. \& N. A. Menezes. 1978. Manual de peixes marinhos do sudeste do Brasil. II. Teleostei (1). São Paulo, Museu de Zoologia da Universidade de São Paulo.

Figueiredo, J. L. \& N. A. Menezes. 1980. Manual de peixes marinhos do sudeste do Brasil. III. Teleostei (2). São Paulo, Museu de Zoologia da Universidade de São Paulo.

Figueiredo, J. L. \& N. A. Menezes. 2000. Manual de peixes marinhos do sudeste do Brasil. VI. Teleostei (5). São Paulo, Museu de Zoologia da Universidade de São Paulo.

Fisher, J. P. \& W. G. Pearcy. 1995. Distribution, migration, and growth of juvenile Chinook salmon, Oncorhynchus tshawytscha, of Oregon and Washington. Fishery Bulletin, 93: 274-289.

Giannini, R. \& A. M. Paiva-Filho. 1995. Análise comparativa da ictiofauna da zona de arrebentação de praias arenosas do Estado de São Paulo, Brasil. Boletim do Instituto Oceanográfico, 43: 141-152.

Gomes, M. P., M. S. Cunha \& I. R Zalmon. 2003. Spatial and temporal variations of diurnal ichthyofauna on surf-zone of São Francisco do Itabapoana beaches, Rio de Janeiro State, Brazil. Brazilian Archives of Biology and Technology, 46: 653-664.

Hackradt, C. W., H. A. Pichler, F. C. Félix-Hackradt, R. Schwarz-Jr, L. O. Silva \& H. L. Spach. 2009. A estrutura da comunidade de peixes em praias de baixa energia do complexo estuarino da Baía de Paranaguá, Brasil. Revista Brasileira de Zoociências, 11: 233-244.

Hajisamae, S., P. Yeesin \& S. Chaimongkol. 2006. Habitat utilization by fishes in a shallow, semi-enclosed estuarine bay in southern Gulf of Thailand. Estuarine, Coastal and Shelf Science, 68: 647-655.

Harrison, T. D. \& A. K. Whitfield. 2006. Temperature and salinity as primary determinants influencing the biogeography of fishes in South African estuaries. Estuarine, Coastal and Shelf Science, 66: 335-345.

Harvey, C. J. 1998. Use of sandy beach habitat by Fundulus majalis, a surf-zone fish. Marine Ecology Progress Series, 164: 307-310.

Inoue, T., Y. Suda \& M. Sano. 2008. Surf zone fishes in an exposed sandy beach at Sanrimatsubara, Japan: does fish assemblage structure differ among microhabitats? Estuarine, Coastal and Shelf Science, 77: 1-11.

Inui, R., T. Nishida, N. Onikura, K. Eguchi, M. Kawagishi, M. Nakatani \& S. Oikawa. 2010. Physical factors influencing immature-fish communities in the surf zones of sandy beaches in northwestern Kyushu Island, Japan. Estuarine, Coastal and Shelf Science, 86: 467-476.

Jovanovic, B., C. Longmore, A. O’Leary \& S. Mariani. 2007. Fish community structure and distribution in a macro-tidal inshore habitat in the Irish Sea. Estuarine, Coastal and Shelf Science, 75: $135-142$.

Kruger, M. \& N. V. A. Strydom. 2010. Spatial and temporal variability in the larval fish assemblage of a warm temperate South African estuary, with notes on the effects of artificial channeling. African Zoology, 45: 195-212.

Laegdsgaard, P. \& C. Johnson. 2001. Why do juvenile fish utilize mangrove habitats? Journal of Experimental Marine Biology and Ecology, 257: 229-253.

Lasiak, T. A. 1986. Juveniles, food and the surf-zone habitat implications for teleost nursery areas. South African Journal of Zoology, 21: 51-56.

Layman, C. A. 2000. Fish assemblage structure of the shallow ocean surf-zone on the eastern shore of Virginia Barrier islands. Estuarine, Coastal and Shelf Science, 51: 201-213.

Levin, P. S., W. Chiasson \& J. M. Green. 1997. Geographic differences in recruitment and population structure of a temperate reef fish. Marine Ecology Progress Series, 250: 23-35.

Macedo, M. J. H., R. V. S. Guedes, F. S. A. Souza \& F. R. C. Dantas. 2010. Análise do índice padronizado de precipitação para o estado da Paraíba, Brasil. Revista Ambiente \& Água - An Interdisciplinary Journal of Applied Science, 5: 201-214.

Mariani, S. 2001. Can spatial distribution of ichthyofauna describe marine influence on coastal lagoons? A Central Mediterranean case study. Estuarine, Coastal and Shelf Science, 52: 261-267.

Masselink, G. 1993. Simulating the effects of tides on beach morphodynamics. Journal of Coastal Research, 15: 180-197.

McLachlan, A. 1983. Sandy beach ecology - a review. Pp. 321-380 In: McLachlan, A. \& T. Erasmus (Eds.). Sandy Beaches as Ecosystems. The Hague, Dr. W. Junk Publishers.

McLachlan, A. \& A. C. Brown. 2006. The Ecology of Sandy Shores. $2^{\mathrm{a}}$ ed. Amsterdam, Elsevier.

Menezes, N. A. \& J. L. Figueiredo. 1980. Manual de peixes marinhos do sudeste do Brasil. IV. Teleostei (3). São Paulo, Museu de Zoologia da Universidade de São Paulo.

Menezes, N. A. \& J. L. Figueiredo. 1985. Manual de peixes marinhos do sudeste do Brasil. V. Teleostei (4). São Paulo, Museu de Zoologia da Universidade de São Paulo.

Monteiro-Neto, C., R. A. Tubino, L. E. S. Moraes, J. P. M. Neto, G. V. Esteves \& W. L. Fortes. 2008. Associações de peixes na região costeira de Itaipu, Niterói, RJ. Iheringia, Série Zoologia, 98: 50-59.

Mourão, J. S. \& N. Nordi. 2003. Etnoecologia de pescadores 
artesanais do estuário do Rio Mamanguape, Paraíba, Brazil. Boletim do Instituto de Pesca, 29: 9-17.

Nelson, J. S. 2006. Fishes of the World, 4 a ed. New Jersey, John Wiley \& Sons.

Niang, T. M. S., A. L. M. Pessanha \& F. G. Araújo. 2010. Dieta de juvenis de Trachinotus carolinus (Actinopterygii, Carangidae) em praias arenosas na costa do Rio de Janeiro. Iheringia, Série Zoologia, 100: 35-42.

Oliveira-Silva, J. T., M. C. Peso-Aguiar \& P. R. D. Lopes. 2008. Ictiofauna das praias de Cabuçu e Berlinque: Uma contribuição ao conhecimento das comunidades de peixes na Baía de Todos os Santos - Bahia - Brasil. Biotemas, 21: 105-115.

Paiva, A. C. G., P. T. C. Chaves \& M. E. Araújo. 2008. Estrutura e organização trófica da ictiofauna de águas rasas em um estuário tropical. Revista Brasileira de Zoologia, 25: 647-661.

Palmeira, L. P. \& C. Monteiro-Neto. 2010. Ecomorphology and food habits of Teleost fishes Trachinotus carolinus (Teleostei: Carangidae) and Menticirrhus littoralis (Teleostei: Sciaenidae), inhabiting the surf zone of Niterói, Rio de Janeiro, Brazil. Brazilian Journal of Oceanography, 58: 1-9.

Paludo, D. \& V. S. Klonowski. 1999. Barra de Mamanguape - PB: Estudo do impacto do uso de madeira de manguezal pela população extrativista e da possibilidade de reflorestamento e manejo dos recursos madeireiros. Série Cadernos da Reserva da Biosfera da Mata Atlântica 16. São Paulo, Conselho Nacional da Reserva da Biosfera da Mata Atlântica.

Pessanha, A. L. M., F. G. Araújo, M. C. C. Azevedo \& I. D. Gomes. 2000. Variações temporais e espaciais na composição e estrutura da comunidade de peixes jovens da Baía de Sepetiba, Rio de Janeiro. Revista Brasileira de Zoologia, 17: 251-261.

Pessanha, A. L. M. \& F. G. Araújo. 2003. Spatial, temporal and diel variations of fish assemblage at two sandy beaches in the Sepetiba Bay, Rio de Janeiro, Brazil. Estuarine, Coastal and Shelf Science, 57: 817-828.

Potter, I. C., P. N. Claridge \& R. M. Warwick. 1986. Consistency of seasonal changes in an estuarine fish assemblage. Marine Ecology Progress Series, 32: 217-228.

Ramos, S., R. K. Cowen, P. Ré \& A. A. Bordalo. 2006. Temporal and spatial distributions of larval fish assemblages in the Lima estuary (Portugal). Estuarine, Coastal and Shelf Science, 66: 303-314.

Ricklefs, R. E. 2003. A Economia da Natureza. $5^{\text {a }}$ ed. Rio de Janeiro, Guanabara Koogan.

Rocha, M. S. P., J. S. Mourão, W. M. S. Souto, R. R. D. Barboza \& R. R. N Alves. 2008. O uso dos recursos pesqueiros no estuário do Rio Mamanguape, estado da Paraíba, Brazil. Interciência, 33: 903-909.
Romer, G. S. 1990. Surf zone fish community and species response to wave energy gradient. Journal of Fish Biology, 36: 279-287.

Rosa, L. C. \& C. A. Borzone. 2008. Uma abordagem morfodinâmica na caracterização física das praias estuarinas da Baía de Paranaguá, sul do Brasil. Revista Brasileira de Geociências, 38: $237-245$.

Short, A. D. 1982. Morphodynamics of a macrotidal beach. Marine Geology, 50: 97-128.

Spach, H. L., C. Santos \& R. S. Godefroid. 2003. Padrões temporais na assembleia de peixes na gamboa do Sucuriú, Baía de Paranaguá, Brasil. Revista Brasileira de Zoologia, 20: 591-600.

Vasconcellos, R. M., J. N. S Santos, M. A Silva \& F. G. Araújo. 2007. Efeito do grau de exposição às ondas sobre a comunidade de peixes juvenis em praias arenosas do Município do Rio de Janeiro, Brasil. Biota Neotropica, 7: 171-178.

Vinagre, C., F. D. Santos, H. N. Cabral \& M. J. Costa. 2009. Impact of climate and hydrology on juvenile fish recruitment towards estuarine nursery grounds in the context of climate change. Estuarine, Coastal and Shelf Science, 85: 479-486.

Whitfield, A. K. 1999. Ichthyofaunal assemblages in estuaries: A South African case study. Reviews in Fish Biology and Fisheries, 9: 151-186.

Woodland, R. J., D. H. Secor, M. C. Fabrizio \& M. J. Wilberg. 2012. Comparing the nursery role of inner continental shelf and estuarine habitats for temperate marine fishes. Estuarine, Coastal and Shelf Science, 99: 61-73.

Wootton, R. J. 1992. Fish Ecology. London, Blackie and Son Limited. Wright, L. D. \& A. D. Short. 1984. Morphodynamic variability of surf zones and beaches: a synthesis. Marine Geology, 56: 93-118.

Xavier, J. H. A., C. A. M. M. Cordeiro, G. D. Tenório, A. F. Diniz, E. P. N. Paulo Jr., R. S. Rosa \& I. L Rosa. 2012. Fish assemblage of the Mamanguape Environmental Protection Area, NE Brazil: abundance, composition and microhabitat availability along the mangrove-reef gradient. Neotropical Ichthyology, 10: 109-122.

Zar, J. H. 1982. Biostatistical Analysis. New Jersey, Prentice Hall.

Submitted May 24, 2013

Accepted November 10, 2013 by Francisco Gerson Araujo

Published March 31, 2014 